\title{
Impact of Kazakhstan's Integration into the Eurasian Economic Community on the Competitiveness of the Country's Agriculture
}

\author{
Alma Batanovna Temyrbekova ${ }^{1}$, Erkyn Batanovich Temyrbek ${ }^{1}$,Nurzhamal Buribaevna Tastandieva ${ }^{1}$, Kuat \\ Zhumabekovich Jandosov ${ }^{1} \&$ Nur Anvarbekovich Aldabergenov ${ }^{2}$ \\ ${ }^{1}$ Department of Economics and Logistics, Almaty Management University, Almaty, Kazakhstan \\ ${ }^{2}$ Higher School of Economics and Business, al-Farabi Kazakh National University, Almaty, Kazakhstan \\ Correspondence: Alma Batanovna Temyrbekova, Almaty Management University, Rozybakiev str., 227, Almaty, \\ 050060, Kazakhstan. Tel: 7-727-302-2136.
}

Received: March 11, 2015 Accepted: March 31, $2015 \quad$ Online Published: May 14, 2015

doi:10.5539/res.v7n7p173 URL: http://dx.doi.org/10.5539/res.v7n7p173

\begin{abstract}
The aim of the article is to identify the impact of Kazakhstan's integration into the Eurasian Economic Community (EAEC) on the competitiveness of the country's agriculture. To achieve target aim scientific works of foreign scholars on the problems of integration and its impact on the national economy have been analyzed. The study found that regional integration has positive and negative effects that can lead to further progressive development of the country and its industries, but also exacerbate existing conflicts and crises. To evaluate the adaptability of Agriculture of Kazakhstan to the country's membership in the EAEC, indicators of industry competitiveness were analyzed: crop yields, livestock productivity, profitability, amount of state support, index of net exports, production of main agricultural products per capita. It was revealed that in agriculture of Kazakhstan competitiveness is lower than in Russia and Belarus in many positions. The world economy has positive experience of management and development of agriculture in terms of integration. Good example is the Common Agricultural Policy (CAP), conducted in the European Union, thanks to which Europe hasn't simply provided itself with all the necessary food, but has become a major supplier of agricultural products to the world market. The article proves the positions of the CAP, which are recommended for use within the EAEC. Currently, in order to support agriculture in Kazakhstan it is necessary to create incentives for the consolidation of small farms, contribute to increase in incomes and salaries for farmers and agricultural workers, increase the amount of state support, significantly expand the range of agricultural products, purchased by the state.
\end{abstract}

Keywords: competitiveness, agriculture, the Eurasian Economic Union Community

\section{Introduction}

In the early 1990's of the twentieth century process of globalization actively began to develop, one element of which is a global economic integration. At the same time Soviet republics had gained independence, and on the world map new sovereign states had appeared. Objective reality caused the need to integrate post-Soviet countries into the world economy, since in the conditions of globalization "any important problem of the modern world cannot be resolved individually. Attempts to act in this way will almost inevitably lead to aggravating other problems, seemingly unrelated to this one" (Tinbergen, 1980).

Global integration is accompanied by economic regionalization: in some regions of the world states create their integration associations. At the same time, the effectiveness of a variety of regional integration groups very differ-from quasi-public level of EU regulation attained in certain aspects to numerous "pseudo" structures that do not provide even a minimal removal of barriers to trade and movement of factors of production (Libman, 2009). Therefore, understanding the driving forces and factors of success or failure of integration initiatives, their impact on the competitiveness of national economies within the framework of integration associations currently become of particular relevance.

The President of Kazakhstan Nursultan Nazarbayev in his speech at Lomonosov Moscow State University on April 28, 2014 said: "It is obvious that in the twenty-first century, regional integration is becoming an important factor in countering the various global risks. Now, in the age of globalization, it is the fundamental question of 
economic and civilizational development of the states, improving their global competitiveness" (Nazarbayev, 2014 ) .

On January 1, 2015 the Eurasian Economic Community (EAEC) began operating. How does it affect the development of agriculture and its associated industries? This question in the scientific literature isn't currently elucidated. Therefore, in this article we have tried to analyze the situation in the agro-industrial complex (AIC) of the country, compare it with the possibilities of agricultural production in the partner countries in the EAEC and make recommendations.

\section{Literature Review}

Grounded theory of impact of integration on the national economy was created by a Canadian-born American scientist Jacob Viner. He identified two main types of effects arising from economic integration: trade creation effect and trade diversion effect. Essence of trade creation is in trade expansion within the integration association. At the same time there is an economy of scale: two or more countries together can form a large market that allows providing a reduction in unit costs of production. Trade diversion effect consists in the economic benefits when the partner country increases its exports to other partner countries. But before creation of the Union these goods were imported from the third countries with lower costs. Thus, the effect of reorientation contributes to increased production in a partner exporting country. However, Jacob Viner notes that when the industry achieves the scale at which it can be provided by optimal amounts and optimal degree of production specialization at some of its plants, the further growth of this industry will bring into action decreasing returns law.

J. Viner supposes that the increase in production within the customs union is limited: if the Customs Union does not provide a significant increase in the mobility of factors of production between countries - members of the union, it does not increase the scale of the national economy in terms of conditions of production, even if there is such an increase in terms of size of the protected outlet market. Thus, J. Viner considers mobility of factors of production is necessary for the growth of the national economy within the framework of integration association, which is characteristic of the common market (J. Viner, 2006).

James Meade is a British economist, winner of the 1977 Nobel Memorial Prize in Economic Sciences. He had critically analyzed works of J. Viner and amplified theory of economic integration effects. He raises the question: Will the use efficiency of the given world's resources increase or decrease due to eliminating previously existing barriers to trade?

J. Meade identifies the following effects of economic integration: trade diversion and trade creation effects.

Based on analysis of the steel market in several European countries, J. Meade concluded that the reorientation of production from low-cost to high cost can occur as a result of integration. It is uneconomic and wasteful. As a result, the global output reduces and in some places there is a falling of overall standard of living. In addition J. Meade notes that a customs union leads to diversion of international trade from all other countries in favor of one of the partners, which now, in terms of customs barriers, takes a privileged position in the market of the importing country. It is uneconomical innovation.

However J. Meade does not deny that a customs union could also lead to the formation of new directions of international trade as one of the partners can carry out the export to other partner's market and bring down the prices. This innovation leads to the displacement of resources in a more efficient and cost effective production system. It all depends on the size of the customs duties for the third countries: the creation of the customs union is more likely to rise than reduce the economic welfare, the higher the initial tariffs on each other's products, from which partner countries have released each other.

As for trade creation effect, J. Meade considers it necessary to balance the economic benefits from some elements of trade creation with economic losses of other elements of trade diversion. That is, as a result of removal of customs duties between countries within the union, the expansion of trade in other industries of economy may occur. It leads to lower costs and economic benefits. J. Meade performed his analysis on the basis of research method: multiplying a value of each element of trade diversion by an increase in unit cost of this type of trade, and multiplying a value of each element of the newly established trade by a unit cost reduction of the established trade. J. Meade believes that trade expansion will compensate losses of the existing trade diversion from low-cost to high cost.

The disadvantage of economic integration J. Meade is also consider the fact that the creation of a customs union means a reduction in income derived from customs duties for the countries forming that union. There can be some losses, which can be countered by gains from trade expansion. Then lost customs revenues should be compensated by increasing other forms of taxation: a new tax here causes as much damage as the old customs 
duty. In this case, the trade creation effects of the reduction of customs duties should be more significant than the adverse effects of trade reducing from the best alternative methods of generating income.

Thus, J. Meade's approach to economic integration is also ambiguous: customs unions can act as a tool leading to more efficient use of resources, but also cannot act this way. It all depends on the specific circumstances of a particular situation (Meade, 1955).

American scientists K. R. McConnell and S. L. Bryu note the effect on scales of production as a result of the integration. By analyzing the process of integration within the $\mathrm{EU}$, they note that the integration creates mass markets, so necessary to achieve "common market" of economy on scale of production by country industries. More efficient production, which is characteristic for large-scale markets, enables European industries to achieve lower costs. These costs historically have been unattainable in separate narrow markets. At the same time, they note that the impact of integration on third countries seems less certain because of rising taxes (Campbell, McConnell, Stanley, \& Bryu, 1992).

American scientists Samuelson P. E. and Nordhaus V. D. note that the growth of economic integration processes is manifested today in a sharp increase in the flow of goods, services and capitals, crossing the borders of different countries. Financial integration of different countries determines profitability growth of international trade. Countries that can ensure efficient use of capital are able to borrow capital from countries with surplus cash reserves. As the positive effects of the integration of product and financial markets, they point out a decrease in prices, increase of innovations and economic growth. However, they note that these benefits are accompanied by a number of quite painful effects:

- Rising unemployment and loss of profit, which occur in cases where highly profitable foreign producers displace local production;

- The global financial crises: a huge wave of international financial crises arising from internal problems of certain countries, due to the close relationship between the individual markets (Paul E. Samuelson, Nordhaus, William D., 2009).

While developing the theory of J. Viner and J. Meade, Russian scientist Shimko P. D. offers a review of the country's accession into the integration union from the perspective of static and dynamic analysis. As part of the static analysis he identifies two possible consequences of accession into the integration trade and economic group:

-Flow-creating effect (trade creation): switching of the country demand and therefore, the consumption from domestic producers with higher costs to the foreign manufacturer with lower costs;

-Flow-diverting effect (trade diversion): switching of the country demand and therefore, the consumption of products outside the Union, which has lower costs to producers with higher costs, but a member of the Union.

In the first case, the removal of barriers to trade provides opportunities for the development of greater specialization in accordance with the theory of comparative advantage. A country can import products from our partners at lower prices, and direct free resources to the development of industries and production with the presence of comparative advantage. In the second case, the imported products from countries that are not members of the Association become more expensive due to the increase of customs duties, and the products of the partner country fall in price because of lower or no customs duties. The production and consumption effect is being formed.

Among the dynamic effects of trade and economic unions Shimko P. D. distinguishes:

-The effect of increase in scale of production;

-Improving the production infrastructure of the participating countries;

-Strengthening the position of each Member State in comparison with the situation of a separate country-outsider;

-Increased competition, which creates a certain climate conducive to the spread of advanced technology;

-Increase in investment.

Shimko P. D. supposes that in terms of common market free movement of factors of production within a particular group of countries should contribute to a more efficient use of combined resources, development of division of labor and specialization of production. However, the full realization of this activity is impeded by differences in the economic policies pursued by member states of the Common Market.

Gurova I. P., while considering consequences of integration, identifies two groups of effects:

1) the competition effect and economies of scale; 
2) the effect of trade and allocation.

Gurova I. P. supposes that larger market formed as a result of integration allows companies of united countries to receive a positive return on the scale of operations, as well as to establish closer cooperation, including a competitive relationship, undermining the position of monopolies and leading to increased efficiency. According to her research, members of the integration unit can receive both internal and external economies of scale. External economies for the company is a result of removing tariffs and other trade barriers in connection with facilitating access to cheaper capital, labor and progressive technologies. Thus, Gurova I. P., as previous authors, notes the movement of capital, labor and technology, which is characteristic of the common market as a factor of economy.

I. P. Nikolaeva along with the positive effects of integration distinguishes negative ones: member-countries separately lose some autonomy in foreign trade policy, but gain significant common benefits, pursue a single economic policy. To the benefits of integration I. P. Nikolaeva refers the following its consequences:

- Receipt of foreign direct investment, which allows increasing production at the expense of new equipment and advanced technologies;

- Integration contributes to higher rates of economic development of the less developed member countries through the use of capitals, technologies, market experience of more developed members of the group;

- Strengthening of the position of the united countries within the large supranational organizations such as the WTO;

- Expanding of cooperation in the political, military, social and other non-economic areas;

- Wider access to financial, manpower, material resources, advanced technologies (World Economy, 2010).

Thus, as it was shown in our research, none of the authors refer to the consequences of integration uniquely: integration has both positive and negative effects. Famous Russian scientist V. P. Kolesov wrote on this subject as follows: "International economic integration is a difficult, uneven, inconsistent and long process as it takes place within the framework and on the basis of different cultural and historical types of society. Each country has its own historically established identity, their own individual concerns and interests" (World Economy. Economy of Foreign Countries, 2001).

\section{Methods}

During the research, we used the methods of scientific abstraction, analysis and synthesis, comparative analysis, statistical sampling. On the basis of scientific abstraction, we abstracted from specific countries and industries and tried to identify the impact of economic integration on any economy and any industry. Through analysis and synthesis, comparative analysis, statistical sampling, we studied indicators of competitiveness of agriculture of Kazakhstan and its partners in EAEC.

Object of analysis-agriculture-is a complex system, which is influenced by many factors. Therefore, the writing of this article, the analysis and recommendations are based on the use of a systematic approach, which is a combination of research methods of complex objects. As part of a systematic approach methodology of the study is based on the use of structural-genetic and functional methods. Genetic aspects related to the study of the transition from traditional to competitive relations. Functional method involves the study of the functioning of modern economic mechanism, reproduction of the economy and its agricultural sector as a whole in a given historical moment. As part of these methodological principles we apply other general theoretical and private methods (collection and compilation of facts, generating of hypotheses, induction and deduction, etc.). These methods allowed us to develop proposals for improving competitiveness of the agricultural sector of Kazakhstan, while switching from positive economy to normative one.

\section{Results}

Currently, there is no uniform methodology for determining the competitiveness of agricultural production. In our opinion, with this ends it is right to use not absolute figures of output in crop and livestock production in a particular country, but the relative figures, as countries differ greatly by territory, area of farmland and population. These indicators include crop production, livestock and poultry productivity, profitability, and others.

Analysis of data on yields of major agricultural crops in Kazakhstan, Russia and Belarus allowed coming to the following conclusions (Table 1). 
Table 1. Yields of certain crops in 2013 in EAES countries*hundredweight from 1 hectare

\begin{tabular}{|c|c|c|c|c|}
\hline Country & $\begin{array}{l}\text { Grain and bean } \\
\text { cultures }\end{array}$ & Sugar beet & Potato & Vegetables \\
\hline Kazakhstan & 11.6 & 267.7 & 181.5 & 238.7 \\
\hline Russia & 22.0 & 442 & 145 & 214.0 \\
\hline Belarus & 34.4 & 485 & 208 & 236 \\
\hline
\end{tabular}

Note. it is compiled by authors on the basis of sources: (Agriculture, forestry and fisheries in the Republic of Kazakhstan, 2014; Agriculture of the Republic of Belarus, 2014; Agriculture, hunting and forestry in Russia, 2014).

The Republic of Belarus on the yield of grains, sugar beets and potato outruns Kazakhstan and Russia. On grain yield Kazakhstan lags far behind its partners in the alliance. This suggests that, despite the fact that grain farming is a basis of agricultural production in Kazakhstan, it is carried out mainly by extensive way. Kazakhstan has a slight advantage in yield of vegetables, but this is due to the fact that the country is located southward of the Russian Federation (RF) and the Republic of Belarus (RB). The lowest yield of potato is in Russia .

In Kazakhstan, the average milk yield per 1 milk cow in 2012 was 2,219 kilograms, or 1.8 times less than in Russia, and 2 times less than in Belarus (Agriculture, forestry and fisheries in the Republic of Kazakhstan, 2014; Agriculture of the Republic of Belarus, 2014; Agriculture, hunting and forestry in Russia, 2014). Kazakhstan lags behind also in other indicators.

An important indicator reflecting the competitiveness of agriculture is a production of main agricultural products per capita (Table 2).

Table 2. Production of main agricultural products per capita in 2013 in EAES countries* kilograms

\begin{tabular}{lllllll}
\hline Country & Grains & Potato & Vegetables & $\begin{array}{l}\text { Livestock } \\
\text { and poultry } \\
\text { for slaughter }\end{array}$ & Milk & $\begin{array}{l}\text { Eggs } \\
\text { (pieces) }\end{array}$ \\
\hline Kazakhstan & 1,070 & 196 & 190 & 92 & 289 & 229 \\
Russia & 645 & 211 & 103 & 56 & 214 & 288 \\
Belarus & 803 & 625 & 172 & 124 & 701 & 418 \\
\hline
\end{tabular}

Note. ${ }^{*}$ it is compiled by authors on the basis of sources: (Agriculture, forestry and fisheries in the Republic of Kazakhstan, 2014; Agriculture of the Republic of Belarus, 2014; Agriculture, hunting and forestry in Russia, 2014).

Most grains and vegetables per capita are produced in Kazakhstan. However, on potato, milk and eggs Kazakhstan lags behind other countries in the EAEC. For these types of products primacy belongs to Belarus.

Health Ministry of Russia in 2010 developed the recommendations on rational standards of consumption of foods that meet modern requirements of a healthy nutrition (Table 3)

Table 3. The recommended amount of consumption of nutrition products ${ }^{*}$

\begin{tabular}{ll}
\hline Product groups & The recommended amount
\end{tabular}

\begin{tabular}{ll}
\hline Bread and pasta per flour, cereals, legumes, in total & \\
including wheat flour, enriched with micronutrients & $95-105 \mathrm{~kg} /$ year $/$ person \\
& $30-40 \mathrm{~kg} /$ year $/$ person \\
Potato & $95-105 \mathrm{~kg} /$ year $/$ person \\
Vegetables and melons & $120-140 \mathrm{~kg} /$ year $/$ person \\
\hline
\end{tabular}


Fruits and berries

Meat and meat products, in total

Including:

beef

lamb

pork

Poultry

Milk and milk products, calculated as the milk

Eggs

Fish and fish products

Sugar

Vegetable oil
90-100 kg/year/person

70-75 kg/year/person

$25 \mathrm{~kg} /$ year / person

$1 \mathrm{~kg} /$ year/person

$14 \mathrm{~kg} /$ year /person

$30 \mathrm{~kg} /$ year /person

$320-340 \mathrm{~kg} /$ year / person

260 pcs

$18-22 \mathrm{~kg} /$ year / person

24-28 kg/year/person

$10-12 \mathrm{~kg} /$ year /person

Note. ${ }^{*}$ source (Order of the Ministry of Health and Social Development of the Russian Federation, 2010)

From the table it is clear that rational consumption rate can be achieved in Kazakhstan, Russia and Belarus on the products of grain production and potatoes. However, rational consumption rate of vegetables for the population cannot be provided by Russia, meat - Russia, milk - Kazakhstan and Russia, and eggs - Kazakhstan. At the same time, the relative abundance of agricultural production is observed in vegetables - in Kazakhstan, meat - Kazakhstan and Belarus, milk - Belarus, eggs - Russia and Belarus. These advantages are the basis for the creation of a unified Eurasian commodity distribution system of agricultural products, raw materials and food (Table 4).

Table 4. Correspondence of agricultural products per capita in the EAEC countries to rational consumption rates of foods that meet the modern requirements of a healthy nutrition

\begin{tabular}{lll}
\hline Country & $\begin{array}{l}\text { Type of product, corresponding to } \\
\text { rational consumption rates }\end{array}$ & $\begin{array}{l}\text { Products type, that do not } \\
\text { correspond } \\
\text { consumption rates }\end{array}$ \\
\hline Kazakhstan & grain, potato, vegetables, meat & milk, eggs \\
Russia & grain, potato, eggs & vegetables, meat, milk \\
Belarus & grain, potato, vegetables, meat, eggs, no \\
& milk &
\end{tabular}

Note. developed by the authors.

At the same time, the real consumption of food does not correspond to the volume of agricultural production (Table 5).

Table 5. Consumption of basic food products per capita in the EAEC countries in 2012* kilograms

\begin{tabular}{llll}
\hline & Kazakhstan & Belarus & Russia \\
\hline Potato & 112 & 186 & 111 \\
Vegetables and melons & 198 & 145 & 109 \\
Fruits and berries & 54 & 64 & 61 \\
Meat and meat products & 71 & 88 & 74 \\
Milk and milk products & 54.6 & 281 & 249 \\
Eggs (pcs.) & 202 & 303 & 276 \\
\hline
\end{tabular}

Note. it is composed according to the source (Agriculture of the Republic of Belarus, 2014; Ministry of Agriculture 
of Russian Federation. National Report, 2014).

*In Kazakhstan a consumption of milk, eggs, fruits is lower the rational norms. In Russia-vegetables and melons, fruits and berries, milk. In Belarus_-fruits, milk.

In world practice, an index of net exports is recognized as an important indicator of competitiveness, reflecting the comparative advantages of products, including agriculture. Index of net exports is determined from the following formula:

$$
\text { NERip }=(\text { Xip-Mip }) /(\text { Xip }+ \text { Mip }) \text {, where Xip - exports, Mip - imports }
$$

It shows for each of the products (or product group) level of export surplus (with a positive index value) or the level of import surplus (with a negative index value). The index value is placed in the range from -1 to +1 . The values of " - 1" and " +1 " are extreme . Other negative values show a degree of imports surplus, and other positive values - the degree of exports surplus.

Table 6 shows the revealed comparative advantage of Kazakhstan in foreign trade in agricultural products with Russia and Belarus.

Table 6. Revealed comparative advantage of Kazakhstan in foreign trade in agricultural products to Russia and Belarus (the index of net exports) ${ }^{*}$

\begin{tabular}{|c|c|c|}
\hline Name & The RF & The RB \\
\hline Meat & -0.82 & -1 \\
\hline Fish & -0.13 & -1 \\
\hline Milk and cream & -0.50 & -1 \\
\hline Butter & -0.81 & -1 \\
\hline Cheese and cottage cheese & -0.93 & -0.997 \\
\hline Eggs, thousand pcs & -1.0 & -1 \\
\hline Potato & -0.72 & -1 \\
\hline Vegetables & 0.45 & -1 \\
\hline Grains & 0.94 & 0.996 \\
\hline Flour & 0.92 & -1 \\
\hline Sugar & -1 & -1 \\
\hline Fruits & 0.59 & 0 \\
\hline Cereals & -0.45 & -1 \\
\hline Juices & -1 & 0 \\
\hline Animal fats & -1 & 0 \\
\hline Vegetable oil & -0.96 & 0 \\
\hline Sausages & -0.998 & 0 \\
\hline Pasta & -0.45 & 0 \\
\hline
\end{tabular}

Note. ${ }^{*}$ calculated by authors.

Now we reveal the comparative advantages of the Russian Federation in relation to the Republic of Kazakhstan and the Republic of Belarus (Table 7). 
Table 7. Revealed comparative advantage of Russia in foreign trade in agricultural products with Kazakhstan and Belarus (the index of net exports)*

\begin{tabular}{lll}
\hline Name & The RK & The RB \\
\hline Meat & 0.82 & -0.99 \\
Fish & 0.13 & 0.58 \\
Milk and cream & 0.50 & -0.99 \\
Butter & 0.81 & -0.99 \\
Cheese and cottage cheese & 0.93 & -0.94 \\
Eggs, thousand pcs & 1 & 1 \\
Potato & 0.72 & -0.99 \\
Vegetables & -0.45 & -0.95 \\
Grains & -0.94 & 0.87 \\
Flour & -0.92 & -0.80 \\
Sugar & 1 & -0.999 \\
Fruits & -0.59 & -0.90 \\
Cereals & 0.45 & 0.26 \\
Juices & 1 & 0.68 \\
Animal fats & 1 & -0.999 \\
Vegetable oil & 0.96 & 0.67 \\
Sausages & 0.998 & -0.99 \\
Pasta & 0.45 & 0.86 \\
\hline
\end{tabular}

Note. ${ }^{*}$ calculated by authors.

Finally, we define the comparative advantages of the Republic of Belarus in relation to the Republic of Kazakhstan and the Russian Federation (Table 8).

Table 8. Revealed comparative advantage of the Republic of Belarus in foreign trade in agricultural products to the Republic of Kazakhstan and the Russian Federation (the index of net exports) ${ }^{*}$

\begin{tabular}{lll}
\hline Name & The RK & The RF \\
\hline Meat & 1 & 0.99 \\
Fish & 1 & -0.58 \\
Milk and cream & 1 & 0.99 \\
Butter & 1 & 0.99 \\
Cheese and cottage cheese & 0.997 & 0.94 \\
Eggs, thousand pcs & 1 & -1 \\
Potato & 1 & 0.99 \\
Vegetables & 1 & 0.95 \\
Grains & -0.996 & -0.87 \\
Flour & 1 & 0.80 \\
Sugar & 1 & 0.999 \\
Fruits & 0 & 0.90 \\
Cereals & 1 & -0.26 \\
Juices & 0 & -0.68 \\
\hline
\end{tabular}




\begin{tabular}{lll}
\hline Animal fats & 0 & 0.999 \\
Vegetable oil & 0 & -0.67 \\
Sausages & 0 & 0.99 \\
Pasta & 0 & -0.86 \\
\hline
\end{tabular}

Note. ${ }^{*}$ calculated by authors.

Thus, Kazakhstan has comparative advantages in trade with Russia on vegetables, grains, flour and fruits, in trade with Belarus - on grains.

Russia has comparative advantages in trade with Kazakhstan on meat, fish, milk, cream, cheese and cottage cheese, eggs, potato, sugar, cereals, juices, animal fat, vegetable oil, sausages and pasta, in trade with Belarus-on fish, eggs, grains, cereals, juices, vegetable oil and pasta.

Belarus has comparative advantages in trade with Kazakhstan in all commodity groups except for cereals, in trade with Russia — on meat, milk and cream, butter, cheese and cottage cheese, potatoes, vegetables, flour, sugar, fruit, animal fats and sausages (Table 9).

Table 9. Commodity headings with comparative advantages of EAEC countries in trade in agricultural products* (in terms of the index of net exports)

\begin{tabular}{|c|c|}
\hline Country & Product Type \\
\hline \multicolumn{2}{|l|}{ Kazakhstan: } \\
\hline In relation to Belarus & grains \\
\hline In relation to Russia & vegetables, grains, flour, fruit \\
\hline \multicolumn{2}{|l|}{ Belarus } \\
\hline \multirow[t]{2}{*}{ In relation to Kazakhstan } & $\begin{array}{l}\text { meat, fish, milk and cream, butter, cheese and cottage cheese, } \\
\text { eggs, potato, vegetables, flour, sugar, fruits, cereals, juices, } \\
\text { animal fats, vegetable oil, sausages, pasta }\end{array}$ \\
\hline & $\begin{array}{l}\text { meat, milk and cream, butter, cheese and cottage cheese, potato, } \\
\text { vegetables, flour, sugar, fruit, animal fats, sausages }\end{array}$ \\
\hline \multicolumn{2}{|l|}{ In relation to Russia } \\
\hline \multicolumn{2}{|l|}{ Russia } \\
\hline In relation to Kazakhstan & $\begin{array}{l}\text { meat, fish, milk and cream, cheese and cottage cheese, eggs, } \\
\text { potato, sugar, cereals, juices, animal fats, vegetable oil, } \\
\text { sausages, pasta }\end{array}$ \\
\hline In relation to Belarus & fish, eggs, grains, cereals, juices, vegetable oil, pasta \\
\hline
\end{tabular}

\footnotetext{
*Note. developed by authors.
}

The level of profitability of agricultural production indicates the degree of efficiency in the use of material, labor and financial resources, as well as the natural resources in the production of agricultural products.

The profitability of agricultural production in the agricultural enterprises in 2013 in Kazakhstan amounted to $17.5 \%$, while in Belarus - 18.6\%. In Russia, the profitability of agriculture in 2013 amounted to 9/3\% (Agriculture, forestry and fisheries in the Republic of Kazakhstan, 2014; Agriculture of the Republic of Belarus, 2014; Agriculture, hunting and forestry in Russia, 2014). In Kazakhstan, the level of profitability in crop production is higher than in livestock (respectively, 22.4 and 7.6\%).

An important indicator of competitiveness is also the amount of state support of agriculture, which is also different in the partner countries. The volume of state support of agriculture to the gross volume of output in agriculture in Belarus is $18 \%$, in Russia-8 \%, while in Kazakhstan-4\% (Servants of the people, 2014). The total support of agriculture (measures that are not distorted and distorting mutual trade) were as follows: in Russia- 6.0 billion 
USD, In Belarus - 2.7 billion USD, or $45.2 \%$ of the Russia's level, in the Republic of Kazakhstan -2.1 billion USD, or $34.8 \%$ of the Russia's level.

Partners of Kazakhstan in the Customs Union have a number of other benefits, based on objective and subjective factors.

Small-scale production prevents competitiveness of domestic food. According to statistics for 2013 in the country $45 \%$ of agricultural products were produced in households. Where $21.5 \%$-are crop production and $75 \%$-are livestock products. In Belarus households produce $24.1 \%$ of the total agricultural production. Where $40 \%$-are crop production, $10 \%$ - are livestock products. In the Russian households produce $41 \%$ of the production industry. Where $39 \%$-are crop production, $43 \%$-are livestock production (agriculture, forestry and fisheries in the Republic of Kazakhstan, 2014; Agriculture of the Republic of Belarus, 2014; Agriculture, hunting and forestry in Russia, 2014).

\section{Discussion}

Kazakhstan's agricultural market is not completely protected from outside intervention. Because of the low efficiency and lack of scale of production a prime cost of production is very high. Purchase prices are set at a level lower than the average costs of production. Competitiveness of the industry is very low.

The analysis presented in the second section of the report showed that the comparative advantages of agriculture in Kazakhstan are rather limited. Therefore, the impact of integration into the EAEC on agriculture of the country may occur in two scenarios: optimistic and pessimistic. The main recommendation of the Eurasian Commission, which must play a positive role in improving the competitiveness of agriculture, is a need to increase state support of the industry from $4 \%$ to $10 \%$. Just because of the generous support of the European Union (EU) production significantly exceeds the demand for food.

The optimistic scenario can be expressed in the positive effects that are described in the first section of the project.

1) Trade creation effect. As a result of integration into the EAEC sales of agricultural products will increase, with the free movement of labor and capital. Trade expansion will compensate losses of existing trade diversion from low-cost to high cost. At the same time it will be switching in demand in Kazakhstan and therefore consumption from domestic producers with higher costs to the Russian or Belarusian producer with lower costs.

2) Economies of scale. As a result, the mobility of factors of production (labor and capital) will improve the conditions of production, which will increase outputs and low production costs. More efficient production, characteristic of large markets, will enable agribusiness industries to achieve lower costs.

3) Trade diversion effect. As a result of integration into the EAEC exports of Kazakhstan's agricultural products to Russia and Belarus will increase. It will contribute to the growth of production in Kazakhstan. Besides, low prices for some agricultural products, imported from Russia and Belarus will facilitate the movement of resources in a more efficient and cost effective production system. There will be opportunities for development of greater specialization in accordance with the theory of comparative advantage. A country can import products from our partners at lower prices, and direct free resources to the development of industries and production with the presence of comparative advantage. Production infrastructure will be improved.

4) Demonstration effect. As part of the EAEC, Kazakhstan's position will strengthen in the international arena as a participating country in comparison with the situation of a country-outsider, especially when joining the World Trade Organization (WTO).

Under the EAEC a certain psychological impact will be given on other countries as a result of acceleration in economic growth, decline in inflation, employment growth in Kazakhstan.

5) As a result of increased competition a certain climate will be created, conducive to the spread of advanced technology. Free movement of factors of production within the EAEC will contribute to more efficient use of combined resources, the development of division of labor and specialization of production. Competitive relations will undermine the position of monopoly, as enterprises in Kazakhstan will be in a more intense competition. Competition will force firms to cut costs to the effective level.

6) As a the result of capital mobility investment in agro-industrial complex of Kazakhstan will increase. Receipt of direct investment to Kazakhstan from Russia and Belarus will allow increasing production at the expense of new equipment and advanced technologies.

7) Economy factor. Kazakhstan will have access to cheaper capital, labor force and progressive technologies.

8) The market outlets of agricultural products will increase, as the total population of the EAEC is more than 170 
million people.

Pessimistic scenario can be expressed in negative effects.

1) As a result of integration into the EAEC, reorientation of foreign trade of the Republic of Kazakhstan from low-cost to high-cost may occur. It can be a diversion of international trade from all other countries in favor of one of the partners, Russia and Belarus, which now, in terms of customs barriers, takes a privileged position in the market of the importing country, which seems uneconomical (flow diverting effect or the trade diversion effect). As a result, there will be growth in prices. The reorientation of trade can lead to losses in outputs and decrease in exports for more effective countries outside the integration bloc.

2) Government revenues will reduce as a result of duty-free movement of not only goods, but also labor and capital.

3) Non-compliance with agreements on equal participation in the EAEC, weak control over the movement of goods and factors of production can lead to outflow of resources from Kazakhstan to more economically robust member of the union. That will transform the country into a backward region. The location of production activities in united countries can be changed: expansion of some sectors and reduction of others. Changes may be unbalanced, and Russia and Belarus may be in a better position than Kazakhstan.

4) At establishing closer integration ties between individual firms of member countries, it may be more widespread oligopolistic collusion, entailing higher prices for the relevant products.

5) Decreasing returns of the scale can arise with the formation of very large companies.

The world practice has accumulated considerable experience in solving agricultural problems of the partner countries of integration groups. Experience of EU deserves a special attention, where since 1957, i. e. since the establishment of the common market, Common Agricultural Policy (CAP) was held on the entire territory of European Union. And until 1992, the costs of agriculture represented 49\% of the EU budget. In 2013 this proportion amounted to 32\% (Common Agricultural Policy, 2014). In 2014-2020 the EU will allocate $38 \%$ of the total budget for this. In this case, it will be spent 312.7 billion EUR on subsidies. This is $76.6 \%$ of the total agricultural budget. $23.4 \%$ or 95.6 billion EUR will be allocated for development of rural regions (Approved by the new Common Agricultural Policy of the EU, 2014).

What valuable it is possible to adopt from experience of EU CAP?

First, the CAP objectives. The main objectives of the Common Agricultural Policy are:

1) Providing farmers with acceptable standard of living. In other words, the EU's agricultural policy is aimed at supporting farm prices and incomes. It is well known that agriculture is the only branch of production with the existing laws of free competition. Therefore to run agricultural business in conditions of monopolized industrial, commercial, etc. market - is the same as to condemn oneself to disparate low incomes.

2) Ensuring consumers with quality products at fair prices. Products of European farmers divided into three groups: for export to third countries, for export to developed countries, and for domestic consumption. We tend to produce products for export better than for its own population.

3) Preservation of agricultural heritage. Agricultural heritage is not only in maintaining the traditions of industrial activity, but cultural and national values, which tend to be the best preserved in the countryside.

Second, the harmonization of policy and its transfer to the supranational level. Currently, each member country of EAEC holds its own agricultural policy. Even amounts of state aid are 4 times more in Belarus and 2 times higher in Russia than in Kazakhstan. Therefore, the formation of a common food market without harmonization of agricultural policy is not possible.

Third, the principles of agrarian policy. In the EU by 1962 three main principles of the CAP had been set:

-The integrity of market. Agricultural market of the member countries should function as a whole. Only in this case the realization of comparative advantages for the benefit of the entire Union is possible;

-Preference products of community. Agricultural policy should be aimed at formation of healthy population. Therefore, production for domestic consumption must be of high quality, ecologically clean, without different gene changes and harmful additives. And the population of the partner countries must be confident in it and prefer products of Union;

-Financial solidarity. In this regard, the EU experience is priceless. Germany and France are the donors of the EU budget, and such agricultural countries as Spain, Greece and Portugal are the largest recipients. 
Fourth, the need to consider the social structure of agriculture and both structural and natural differences between the various agricultural regions. Kazakhstan, Belarus and Russia - are three major countries. Their territories are located in different natural zones. There are different national traditions which have been preserved especially in rural areas. Therefore, we cannot completely neutralize all forms and methods of support in all regions of these countries.

Fifth, a set of mechanisms for the implementation of agricultural policies. The West has been tested and successfully uses such techniques as:

-The system of support prices of farm products. In the EU system of support prices includes: targeted or oriented prices, guaranteeing a certain income; the threshold prices for imported products; export subsidies for exports; intervention prices, or minimum prices at which the state procurement agencies buy products from farmers;

-Taxing imports from third countries;

-Import quotas to limit the number of imported products;

-Direct subsidies for farmers. Moreover, subsidies were a tool to encourage farmers to grow those crops which in the EU countries are not enough, there is a tool reducing economic incentives of overproduction. Subsidies were mainly paid for the land on which a certain culture was cultivated, and not on the total number of cultural products. In the West, it is believed that to store and place the excess production is a wastefulness of resources.

Sixth, the harmonization of legislation. Existing differences on such items as allowance or prohibition of conservants, food colorings, hormones and other substances in food, marking rules, animal diseases, etc. must be leveled, because they can cause problems both in domestic trade of partner countries and in trade with third countries.

Seventh, the transparency of costs on agriculture support. The financial resources allocated from the general budget to support farmers in a given country should be controlled, transparent, well known and does not infringe upon the interests of any party.

Eighth, the unification of food prices, as their difference affects the cost of raw materials and labor force, and can provoke intensification of competition in other areas.

Ninth, the support of ecologically clean farming methods, environmental protection. In the EU, for this purpose in 2005 special subsidies were developed: if the land is processed in accordance with environmental regulations, additional benefits are provided. In addition, the agricultural policy of the European Union for the period 2014-2020 provides that $30 \%$ of all subsidies are got by farmers practicing crop rotation, preserving pastures and nature.

CAP experience shows that due to its implementation the EU countries have become major exporters of agricultural products, fully providing their population with food.

The world practice shows that large farms are the most effective in the agricultural sector. The advantage of large-scale production over small experience was proved by the USA experience, where $72 \%$ of small farmers, owning $31 \%$ of machinery and equipment, concentrating $44 \%$ of the workforce, produce only $10 \%$ of gross farm income. At the same time they use the land and equipment 4 times, and labor 7 times worse than the other $28 \%$ of large farms. Small farms cannot use advanced technology and the latest technologies with total efficiency (Semenov, 1999).

In a market economy the trend of concentration and consolidation of farms is a natural regularity. In countries where the market economy has long been functioning effectively, the concentration of farms was carried out by converting them from the individual forms of partnership and agrocorporation. In addition, there has been widely used co-operation.

Currently, the process of consolidation of farms in Kazakhstan has being received little attention. On the contrary, taxation is increasing, in particular, land tax. Small farms do not have incentives to cooperation and integration, as in consequence of the transition to other forms of business, the tax burden significantly increases. Therefore, the government needs to create an enabling environment for the concentration and centralization of capital in the agricultural sector by improving the system of tax subsidies and subventions.

State in the Republic of Kazakhstan establishes procurement prices for a limited range of agricultural products (wheat, soybeans, barley). In essence, there is a lobbying of interests of grain-producing enterprises, especially the large cartels. Livestock products, vegetables, fruits, and others remain outside the state support. It will lead to one-sided development of the industry. It is necessary to expand the range of products that get under state order and public procurement. There is a need for real help to all agricultural producers. In the EU, the government 
regulates the prices of more than 270 kinds of agricultural products (G. Pavlov, 2004).

\section{Conclusion}

Based on the research we have come to the following conclusions:

1) The economic integration affects the competitiveness of national economies in two ways: towards dynamism and strengthening and towards aggravation of contradictions and decrease of competitiveness. It all depends on correct economic policy, correct evaluation of the economic and political situation in the country, presence or absence of economic resources. In the economic literature effects arising due to economic integration are revealed: trade creation effect, trade diversion effect, economies of scale, demonstration effect, domino effect, which may have both positive and negative consequences.

2) Analysis showed that the comparative advantages of the AIC of Kazakhstan are rather limited. Therefore, the impact of integration in the EAEC on agriculture of the country may occur in two scenarios: optimistic and pessimistic. The main recommendation of the Eurasian Commission, which must play a positive role in increasing the competitiveness of agriculture, is a need to increase state support of the industry from $4 \%$ to $10 \%$.

3) To solve agricultural problems in the framework of the EAEC it should be adopted a progressive international experience, in particular, of the Common Agricultural Policy (CAP) of the European Union in the following positions: CAP objectives; harmonization of policy and its transfer to the supranational level; the principles of agricultural policy; the need to consider the social structure of agriculture and both structural and natural differences between the various agricultural regions; a set of mechanisms for the implementation of agricultural policy; harmonization of legislation; transparency of costs on agriculture support; unification of food prices; support of ecologically clean farming methods, environmental protection.

The formation of large agribusiness on a basis of small businesses through their integration and concentration will contribute to improving competitiveness of agro-industrial complex of Kazakhstan, as international experience shows a high efficiency in the agricultural sector of large business.

Formation of incentives to labor for hired farm workers is an important factor in the growth of labor productivity, and respectively, the competitiveness of agricultural production.

Increasing the size of state support for agricultural production must go, among other things, in the direction of expanding the range of agricultural products purchased by the state.

\section{References}

Akopova, E. S., Voronkova, O. N., \& Gavrilko, N. N. (2001). Mirovaya ekonomika i mezhdunarodnye ekonomicheskie otnosheniya. The world economy and international economic relations (p.416). Rostov-on-Don: "Phenix" publishing house "Phoenix".

Campbell, R., McConnell, S. L., \& Bryu. (1992). Ekonomiks: Principy, problemy i politika. Economics: Principles, Problems and Policies, 2, 400. Trans. from English. Baku, publishing house "Azerbaijan".

Edinaya selskohozyaistvennaya politika Evropeiskogo soyuza. (2008). Common Agricultural Policy of the European Union. Retrieved from https://ru.wikipedia.org/wiki

Gurova, I. P. (2008). Mirovaya ekonomika. World economy (p. 394). Moscow: publishing house "Omega-L".

Kolesov, V. P., \& Osmova, M. N. (Eds.). (2001). Mirovaya economika. Economika zarubezhnyh stran. In World economy. Economy of foreign countries (3rd ed, p. 480). Textbook. Moscow: Publishing house "Flinta".

Kontseptciya soglasovannoi (skoordinirovannoi) agropromyshlennoi politiki gosudarstv-chlenov Tamozhennogo soyuza i Edinogo ekonomicheskogo prostranstva. (2011). Conception of concerted (coordinated) Agrarian Policy of the Member States of the Customs Union and the Common Economic Space. Retrieved from http://www.eurasiancommission.org/ru/Lists/EECDocs/635055949507925323.pdf

Libman, A. M. (2009). Modeli ekonomicheskoi integracii: Mirovoi i postsovetskii opyt: Dissertaciya ... doktora ekonomicheskih nauk. Model of economic integration: World and post-Soviet experience: The dissertation of ... Doctor of Economics (p. 391). Retrieved from http://www.dslib.net/economika-mira/modeli-jekonomicheskoj-integracii-mirovoj-i-postsovetskij-opyt.html

Meade, J. (2007). Teoriya tamozhennyh soyuzov. The theory of customs unions. Retrieved from http://seinstitute.ru/Files/Veh6-45_Meade.pdf

Ministerstvo selskogo hozyaistva Rossiiskoi Federacii. Nacionalnyi doklad "O hode i rezultatah realizacii v 2013 godu gosudarstvennoi programmy razvitiya selskogo hozyaistva i regulirovaniya rynkov 
selskohozyaistvennoi produkcii, syr'ya i prodovolstviya na 2013-2020 gody". (2014). Ministry of Agriculture of the Russian Federation. National report "On the progress and results of the implementation in 2013 of the state program of agricultural development and regulation of agricultural products, raw materials and food for 2013-2020". Retrieved from http://government.ru/govworks/57/

Mirovaya economika. (2010). World economy (p. 240). Textbook. Moscow: Publishing house "Prospect".

Nazarbaev, N. A. (2012). Ot idei Evraziiskogo soyuza-K novym perspektivam evraziiskoi integracii. In From the idea of the Eurasian Union-to new prospects of Eurasian integration. Retrieved from http://akorda.kz/ru/page/page_216601_vystuplenie-prezidenta-respubliki-kazakhstan-n-a-nazarbaeva-v-mos kovskom-gosudarstvennom-universit

Odobrena novaya edinaya selskohozyaistvennaya politika ES. (2006). New Common Agricultural Policy of the $E U$ is approved. Retrieved from http://www.fermer.org.ua/novosti/odobrenanovaja-edinaja-selskohozjaistvenaja-politika-es-15460.html

Pavlova G. Strane nuzhna novaya agrarnaya politika. (2004). The country needs a new agricultural policy the Economist, 4, 83-88.

Samuelson, P. E., Nordhaus W. D., \& Ekonomika. (2009). Economics (18th ed., p. 1360). Transl. from English. M.: OOO "I. D. Williams".

Selskoe hozyaistvo respubliki Belarus. Statisticheskij sbornik. (2014). Agriculture of the republic of Belarus. Statistical collection. Minsk. Retrieved from http://www.belstat.gov.by

Selskoe hozyaistvo, ohota i ohotnich'e hozyaistvo, lesovodstvo v Rossii. (2014). Stat.sb./Rosstat. Agriculture, hunting and forestry in Russia. 2014: Statistical compilation publishing house "Rosstat" (p. 462).

Selskoe, lesnoe i rybnoe hozyaistvo v Respublike Kazahstan. Statisticheskii sbornik / na kazahskom i russkom jazykah (2014). Agriculture, forestry and fisheries in the Republic of Kazakhstan. Statistical compilation / in Kazakh and Russian languages (p. 198).

Semenov B. Novyi kurs agrarnoi politiki. Ekonomist. (1999). New course of agricultural policy economist, 1, 12-16.

Shimko, P. D. (2010). Mezhdunarodnaya ekonomika: ucheb. Posobie. In International Economics: Textbook (p. 752). M.: Publishing house "Yurait".

Slugi naroda. Ministr selskogo hozyaistva RK Mamytbekov A. (2000). Servants of the people. Minister of Agriculture of the RK, Mamytbekov A. Retrieved from http://www.ktk.kz/ru/programs/slugi_naroda/

Tinbergen, Y. (1980). Peresmotr mezhdunarodnogo poryadka. In A. A. Ryvkina (Ed), Review of the international order general (p. 251). M .: Progress.

Viner, J. (2006). Problema tamozhennogo soyuza. Vehi ekonomicheskoi mysli. T. 6 Mezhdunarodnaya ekonomika. In A. P Kireyev (Ed.), The Customs Union Issue. Milestones of economic mind (Vol. 6, pp. 696-705). International Economics. Moscow:publishing house "TEIS".

\section{Copyrights}

Copyright for this article is retained by the author(s), with first publication rights granted to the journal.

This is an open-access article distributed under the terms and conditions of the Creative Commons Attribution license (http://creativecommons.org/licenses/by/3.0/). 